\title{
The impact of changing food choices on the blue water scarcity footprint and greenhouse gas emissions of the British diet: The example of potato, pasta and rice.
}

Tim Hess*1, Julia Chatterton ${ }^{1,2}$, Andre Daccache ${ }^{1}$ and Adrian Williams ${ }^{1}$

* corresponding author. t.hess@cranfield.ac.uk. School of Energy, Environment and Agrifood, Cranfield University, Bedford, MK43 OAL, UK. +44 1234750111.

1. School of Energy, Environment and Agrifood, Cranfield University, Bedford, MK43 0AL, UK.

2. Present address: SEAC, Unilever R\&D, Colworth Park, Sharnbrook, Bedfordshire, MK44 1LQ, UK.

\section{Highlights}

- Households in the UK are consuming more rice and pasta and fewer potatoes.

- Environmental burdens of portions of potatoes, pasta and rice were compared.

- Rice has higher greenhouse gas emissions and blue water scarcity footprint.

- Irrigation water for rice and durum wheat comes from areas of higher scarcity.

- Changing consumption has increased environmental burdens.

\begin{abstract}
Food production is a major contributor to a country's environmental burden. However, the burdens associated with individual foods vary significantly due to differing agricultural systems and locations, post-harvest storage, manufacturing and transport requirements. Dietary choices can therefore have a significant impact on the overall burdens associated with food consumption. Previous studies have generally considered changes in the proportion of animal-based foods in the diet or changes to a vegetarian, or a vegan diet. Using a life cycle assessment approach and data from published sources supplemented by original analysis, we estimated the blue water scarcity footprint and greenhouse gas emissions associated with the production, manufacture and distribution of three popular starchy carbohydrate foods as consumed in the United Kingdom - British fresh potatoes, Italian dried pasta and Indian dried basmati rice. Although similar to pasta in terms of greenhouse gas emissions per unit carbohydrate, when considered on the basis of typical portion size, potatoes have lower greenhouse gas emissions than pasta or basmati and the blue water scarcity footprint of basmati is two orders of magnitude greater than potatoes or pasta. The increasing preference for pasta and rice and reduction in household purchases of fresh potatoes in the United Kingdom over the period $1981-2010$ has resulted in an increase in blue water scarcity footprint and a transfer of burdens from the United Kingdom to Italy and India, however the increased greenhouse gas emissions associated with rice and pasta has been, more or less, compensated by a reduction in emissions associated with purchases of potatoes. This paper has shown that dietary choices within food groups (in this case starchy carbohydrates) have a significant impact on an individual's contribution to greenhouse gas emissions and blue water scarcity footprint. The life cycle assessment approach is useful for understanding where the impacts of dietary choices occur and can inform the supply chain about where efforts should be targeted to reduce those impacts.
\end{abstract}

Keywords: Carbohydrate; Diet; Life Cycle Assessment; Portion size; UK.

\section{Introduction}

The processes required to produce food create burdens on the environment; land is appropriated for agriculture; agriculture contributes to greenhouse gas emissions, acidification and eutrophication; and resources are consumed. The environmental impacts of the production and distribution of individual foods vary considerably, depending on the life cycle of the product; the geographical location of production and consumption; and the degree of post-harvest processing. 
Therefore the contribution of an individual's diet to their overall environmental footprint depends on what they eat as well as how much they eat and where the food was produced. Most studies on the environmental burdens of food consumption have concentrated on substituting food groups with high environmental burdens (such as animal based products) for those, usually plant based, with lower burdens either through changing to a vegetarian or vegan diet (e.g. Hallström, 2015; Vanham et al., 2013) or by changing the proportion of animal based products in the diet (e.g. Hallström, 2015; Hess et al., 2015,Verain, et al., 2015). However, there is significant variation in the potential environmental burdens within a food group dietary preferences can change over time.

Potatoes have traditionally been a staple part of the British diet (Weichselbaum, 2010) and in the early 1980s, UK household purchases of fresh potatoes (expressed per unit of carbohydrate) were more than 10 times that of alternative starchy carbohydrates such as rice and pasta (after Defra, 2013). However, there has been a trend in UK household purchases away from fresh potatoes and towards pasta and rice, particularly since the early 1990s (Figure 1). Per capita fresh potato purchases in 2006 - 2010 were 55\% lower than the 1981 - 1985 average, whilst purchases of rice and pasta increased more than threefold over the same period (Defra, 2013). It has been estimated that consumption of rice in the UK has risen more than five-fold since 1974 (Schenker, 2012); a trend which is recognised across Europe, where rice is generally more positively perceived by consumers (Supakornchuwong and Suwannaporn, 2012).

Potatoes, pasta and rice have very different life cycles and therefore potentially different environmental burdens, and the observed change of eating habit has implications for both the magnitude and location of the impact. Many studies have estimated the life-cycle impact of food products or diets on a single impact indicator which may conceal significant trade-offs between impacts and lead to inappropriate conclusions about the sustainability of particular foods or diets (Ridoutt et al., 2014; Brodt et al., 2013). In this study we consider both greenhouse gas emissions and water consumption.

Greenhouse gas emissions result from the use of fossil fuel and emissions from the land. The use of fossil fuel in the manufacture of inputs; agriculture; transport and refrigeration in the supply chain (Defra, 2009a); and domestic storage and cooking of food (Defra, 2008; Defra, 2009b) emits mainly carbon dioxide $\left(\mathrm{CO}_{2}\right)$ and some trace gases such as carbon monoxide (CO). The extraction and refining of fossil fuels (JRC, 2013) and the cultivation of rice in paddies (Misra and Verma, 2014) also results in the emission of methane $\left(\mathrm{CH}_{4}\right)$ which has a global warming potential (GWP) of 25 times that of $\mathrm{CO}_{2}$ on a 100 year timescale (Forster et al., 2007). Nitrous oxide $\left(\mathrm{N}_{2} \mathrm{O}\right)$ emissions are caused by the turnover of nitrogen $(\mathrm{N})$ in soils; some fertiliser manufacture; and nitrate leaching (Williams et al., 2006) which has a GWP of 298 (IPCC, 2007), whilst refrigeration during transport emits refrigerants (such as R404a) with a GWP in the thousands (Defra, 2009b). Using a life cycle assessment approach, Audsley et al. (2009) created a detailed inventory of greenhouse gas emissions of UK food consumption. This included agricultural production, manufacturing, distribution and consumption. The total direct greenhouse gas emissions attributable to UK food (excluding land use change) was $152 \mathrm{Mt} \mathrm{CO}_{2} \mathrm{e}$, representing about $20 \%$ of the total UK consumption emissions and values in the range of $15 \%$ to $28 \%$ have been cited for other countries (Garnett, 2011).

Water is an essential part of all food production systems being used for crop irrigation, livestock watering, processing, manufacturing and cooking. Large volumes of water are required to support human food consumption and agricultural products account for $86 \%$ of the water consumed in the support of the global population (Hoekstra and Chapagain, 2007). Although water is used in food processing and manufacture as an ingredient; for washing; and in the production of inputs (such as agrochemicals, fertilizers and energy); by far the largest proportion of the water consumed in food production relates to the growing of crops (Mekonnen and Hoekstra, 2011) and raising of animals (Mekonnen and Hoekstra, 2012). Hess et al. (2015a) estimated that an average of 2,400 litres of water per person per day is required to produce the food consumed in the UK. Although only $7 \%$ of 
this is "blue" water, that is, withdrawn from surface and ground water resources (Falkenmark, 1995), much of this withdrawal occurs in locations that experience a higher degree of water stress, especially for foods imported from Spain, South Africa, Egypt and India.

This study aims to evaluate the impact of changing dietary preferences within a food group on the footprint of consumers in the UK, by comparing the greenhouse gas emissions and blue water scarcity footprint of fresh potatoes with their main competitor products, rice and pasta, as found at the point of sale in the mainstream retail environment. It draws on evidence reviewed on behalf of the Potato Council by the same authors (Williams, et al., 2013).

For comparison, the following scopes were defined:

- Potatoes: Fresh, British-grown pre-packed white potatoes, as sold in a standard $2.5 \mathrm{~kg}$ plastic bag.

- Pasta: Dried, Italian pasta, produced from Italian-grown durum wheat (excluding speciality pasta) as sold in a standard $1 \mathrm{~kg}$ retail pack.

- Rice: Dried, Indian basmati as sold in a standard $1 \mathrm{~kg}$ retail pack.

Potatoes are predominantly a domestic grown crop. More than half of the UK potato retail market is fresh potatoes and imports only account for around $10 \%$ of consumption (PCL, 2012). In addition to greenhouse gas emissions associated with growing the crop, a significant proportion of the British crop is stored in cooled stores and fresh potatoes are bulky to transport resulting in higher fossil fuel use. Supplementary irrigation is used to ensure crop yield and quality (Hess et al., 2015b) and water is used for washing, dust suppression, vehicle wash-down and sanitation in the pack-house.

Pasta (except speciality pastas) is made from semolina from durum wheat. One third of European durum wheat is from Italy (Eurostat, 2013) where it is grown as a winter crop. Supplementary irrigation is used, especially in the drier regions of the south (e.g. Puglia and Sicily), and small amounts of water are used for general farm practices (washing, cleaning, and spraying). Unlike potatoes or rice, water is also an ingredient in the manufacture of pasta.

About $50 \%$ of all rice sold in the UK is basmati (Tilda, 2014) which is only grown in specific regions of India and Pakistan therefore transport distances to Britain are high. Because of the practice of growing rice in flooded, anaerobic soil conditions, methane is emitted from paddy fields (Misra and Verma, 2014) producing both greenhouse gas emissions that are not associated with potatoes or pasta and high water use.

\section{Methods}

Estimates of greenhouse gas emissions and water consumption at each stage, up to the point of delivery to retail, have been based a review of literature, with supplementary analysis where appropriate. In all cases, the greenhouse gas emissions and water consumption have been estimated according to stage of production, that is, primary production (including greenhouse gas emissions and water consumption associated with inputs where applicable); storage (in the case of potatoes); packaging, processing; and distribution (Figure 2). Although greenhouse gas emissions are associated with transport to the home and cooking; and water is used in cooking; this study stops at the point of retail. The wide range of cooking methods available for the three products confounds differences among products. For example, the method of cooking (e.g., boiling, baking or roasting of potatoes), the choice of fuel source (e.g., gas or electricity); the appliance (e.g., conventional oven or microwave) and consumer behaviour can significantly affect the energy required to cook food (Hager and Morawicki, 2013). Also, the potential post-retail wastage rates are different. For example, potatoes are likely to incur higher losses in the home as they are more perishable than dried pasta or rice, but wastage rates are influenced by behavioural factors that are beyond the scope of this paper. The following describes the principles used in those sources. 


\subsection{Greenhouse gas emissions}

Greenhouse gas emissions were quantified using data from life cycle assessment, or similar, studies that quantified direct (e.g. nitrous oxide from fertiliser use) and indirect emissions (e.g. emissions associated with the manufacture of fertiliser) incurred in production. The sum of greenhouse gas emissions from all stages in the life cycle is the greenhouse gas emissions per unit product (also called the product carbon footprint). In line with agricultural, emission factors for each source were taken from the IPCC (2006) guidelines. Greenhouse gas emissions data for inputs (such as nitrogen fertiliser, electricity, diesel or gas) were taken from public or commercial inventories (e.g., the European Reference Life Cycle Data System core database (JRC, 2013), Ecoinvent (2014)). Additional data were required for some aspects, such as converting "end of pipe" exhaust emissions for diesel into those that include the overheads of extraction and distribution, some processing and transport.

Uncertainty in the estimation of greenhouse gas emissions relates to the activity data (e.g. quantity of fertiliser applied) and the emission factors (e.g. emission of $\mathrm{N}_{2} \mathrm{O}$ per unit of $\mathrm{N}$ applied). The uncertainties associated with diffuse emissions from agriculture are typically larger than those from fossil energy use and cannot readily be calculated by analytic methods. Instead, a stochastic model of greenhouse gas emissions was constructed in Microsoft Excel, using @Risk add-on (www.palisade.com), that included probability distribution functions for the activity data and emission factors to generate estimates of uncertainty (Wiltshire, et al., 2009).

\subsection{Blue water scarcity footprint}

The potential impact on freshwater scarcity of water used in food production depends on the "type" of water. "Green water" (Falkenmark, 1995), that is rainfall that contributes to the growth of crops used at the point where it falls, has only agricultural, forestry or environmental uses, whereas water that has been withdrawn from surface or groundwater resources ("blue water") is in competition with other industrial, domestic and environmental uses. It therefore has a greater opportunity cost. However, not all blue water that is "used" is subsequently "consumed". Water is assumed to have been consumed if it has been evaporated (or transpired) to the atmosphere, incorporated in a product, or transferred out of the drainage basin (ISO, 2014). Water that is used, but not consumed, (e.g., water that has been used for washing potatoes, treated and returned in good condition) is available for other downstream uses in the river basin. It is only the consumed blue water which has an impact on water resource scarcity.

Blue water consumption in the growing stage is defined as the difference between crop water use under irrigated and rain fed conditions (Hoekstra et al., 2011) and can only be estimated using agroclimatic models. However, not all crops that receive irrigation are given all the water required to make up the deficit between potential and rain-fed water use - water availability may be constrained or it may not be economic to fully satisfy the irrigation requirements. As basmati is a wetland rice, it is always irrigated, but for potatoes and pasta, the estimates of blue water consumption have been weighted according to the proportion of the crop that is irrigated in each region of production.

The total blue water consumption does not in itself reflect the potential impact on blue water scarcity. For example, water withdrawn from a water-stressed catchment is likely to have a significantly higher impact on water scarcity than an equivalent volume taken from a catchment where water is abundant (Hess, et al., 2014). It is therefore critical that the blue water consumption is put into the context of water scarcity in the place of withdrawal. There is, as yet, no universally preferred method for characterising the impacts of water withdrawal or consumption (Kounina et al., 2013) however, the Water Stress Index (Pfister et al., 2009) can be used as general screening indicator for blue water consumption according to degree of water stress in the region of production (Ridoutt et al., 2010). A water footprint that considers only the impact of water consumption on water scarcity is known as a "water scarcity footprint" (ISO, 2014). 
A global map of water stress index (Pfister et al., 2014) was used to derive water stress index for each region within the three producing countries. The blue water scarcity footprint, WSF, I $\mathrm{H}_{2} \mathrm{Oeq} / \mathrm{kg}$, was then estimated from the specific blue water consumption, production and the water stress index for each region, weighted by the volume of production in each region. The weighted water consumption was then normalized by the global average water stress index, WSlaverage, which is 0.602 (Ridoutt and Pfister, 2010).

$$
W S F=\frac{\sum \frac{\mathrm{BWC}_{i} \times \mathrm{WSI}_{i} \times P_{i}}{\mathrm{WSI}_{\text {average }}}}{\sum P_{i}}
$$

Where, $B W C_{i}$ is the specific blue water consumption, $\mathrm{m}^{3} / \mathrm{t}, \mathrm{i}$ is the region of production and $\mathrm{P}_{\mathrm{i}}$ is the volume of production in region $\mathrm{i}$, $\mathrm{t}$.

Uncertainties in blue water consumption are difficult to estimate. There will be significant uncertainties in the estimation of blue water consumption associated with uncertainties in the modelling of crop water consumption and cropping seasons (Zhuo et al., 2014); crop yield; and the degree of irrigation. As the sources used did not cite any uncertainty estimates, a quantitative uncertainty analysis was not possible. However, it has been estimated that uncertainties in the total water consumption of a crop per unit of production may be $\pm 30 \%$ (Zhuo et al., 2014).

\subsection{Allocation}

The greenhouse gas emissions and blue water consumption of the crop grown must be allocated between the main product (in this case potatoes, pasta and rice as packed) and co-products of lower value. For example, bran, groat and meal are co-products of basmati. The allocation factor of Chapagain and Hoekstra (2011) was used for milled rice. For potatoes a $4 \%$ post-harvest and a $1 \%$ pack-house loss was assumed (WRAP, 2011). Although pack-house waste may be used as feed for anaerobic digestion and have an energy value, we have assumed zero value as a worst case estimate. In this study, greenhouse gas emissions and blue water consumption were allocated by the relative values of product streams and wherever possible the same allocation factors have been used for greenhouse gas emissions and blue water consumption.

\subsection{Functional unit}

The three foods considered are very different in terms of water content and nutritional value, therefore comparison of life cycle analyses on the basis of weight does not adequately reflect the commutability of the foods. In this study, the greenhouse gas emissions and blue water consumption were evaluated in terms of net weight (NW, that is weight of food, as packed, at the point of retail), carbohydrate and typical portion size (Table 1). Standard estimates of carbohydrate were taken from Food Standards Agency (2002) however, portion size is more ambiguous. Retail packaging contains information on recommended portion sizes of raw foods and a number of studies have analysed actual portion sizes of cooked foods consumed in the UK. However, there are large ranges in the figures quoted, especially for potatoes. Having reviewed the information on retail packets and actual consumption reported by Wrieden and Barton (2006) and Mills and Patel (2002), typical portion sizes of $175 \mathrm{~g} \mathrm{NW}$ for potatoes and $75 \mathrm{~g} \mathrm{NW}$ for both pasta and rice were selected. These are similar to the rounded values of the median recommendations by retailers reported by Lewis et al. (2012). 


\section{Results}

\subsection{Greenhouse gas emissions}

\subsubsection{Potatoes}

Wiltshire et al. (2009), Williams et al. (2010) and Webb et al. (2013) reported national-level, systemsbased life cycle assessment studies for primary production and storage of maincrop potatoes up to the farm gate including post-harvest processing, grading and storage. Wiltshire et al. (2009) also assessed the greenhouse gas emissions of maincrop potatoes using a mixture of empirical farm data and generic data sources, although this was based on the publicly available specification PAS2050 (BSI, 2008) and was therefore not identical to the life cycle assessment studies in terms of boundary conditions (e.g., capital items, such as tractors were excluded). Despite differences in methods, data and boundaries, the estimates of greenhouse gas emissions of primary production of maincrop potatoes are remarkably similar, ranging from 0.10 to $0.17 \mathrm{~kg} \mathrm{CO}_{2} \mathrm{e} / \mathrm{kg} \mathrm{NW}$ (Table 2).

Williams et al. (2006), Wiltshire et al. (2009) and Williams et al., (2010) included potato storage and Webb et al. (2013) also included grading and transport to the regional distribution centre (RDC). Whereas Williams at al. (2010) reported values for generic maincrop potatoes, the study of Webb et al. (2013) was specifically for pre-pack potatoes for the retail market from September to July. This allowed for the higher supply of early potatoes during the summer but may slightly underestimate the greenhouse gas emissions for a year-round supply of pre-pack maincrop potatoes. These estimates were adjusted to reflect the progress of harvesting, filling and sequential emptying of stores. An average of $0.023 \mathrm{~kg} \mathrm{CO}{ }_{2} \mathrm{e} / \mathrm{kg} \mathrm{NW}$ was assumed for storage which is lower than the estimate of Williams et al. (2010) but was derived from more mechanistic model of energy use and used the same source as Webb et al. (2013). Greenhouse gas emissions associated with packaging were not reported in the studies above, but a typical weight of polyethylene film around a $2.5 \mathrm{~kg}$ pack of potatoes is $7.5 \mathrm{~g}$ and amounts to $0.006 \mathrm{~kg} \mathrm{CO}_{2} \mathrm{e} / \mathrm{kg} \mathrm{NW}$ (based on Ecoinvent, 2014). Together, grading, packing and transport to the RDC contributed $0.15 \mathrm{~kg} \mathrm{CO}_{2} \mathrm{e} / \mathrm{kg} \mathrm{NW}$ to the greenhouse gas emissions. Potatoes are refrigerated whilst in the RDC, but are usually transported to retail at ambient temperatures (Tassou et al., 2008). Based on Tassou et al. (2008), transport from the RDC to retail adds a further $0.014 \mathrm{~kg} \mathrm{CO} 2 \mathrm{e} / \mathrm{kg} \mathrm{NW}$.

The uncertainty analysed by Röös et al. (2010) for potatoes gave a single coefficient of variation of $23 \%$ and was used for UK potatoes. The estimated greenhouse gas emissions at each stage from various studies are given in Table 2 . The total greenhouse gas emissions total for maincrop potatoes is $0.24-0.38 \mathrm{~kg} \mathrm{CO}_{2} \mathrm{e} / \mathrm{kg} \mathrm{NW}$ (mean $=0.31 \mathrm{~kg} \mathrm{CO}{ }_{2} \mathrm{e} / \mathrm{kg} \mathrm{NW}$ ) (Table 2).

\subsubsection{Pasta}

Two European companies, Barilla (Barilla, 2011) and De Cecco (De Cecco, 2010) produced Environmental Product Declarations (EPDs) for dried pasta to the RDC. Bevilacqua et al. (2007) also conducted a life cycle assessment of pasta, but the results were expressed in aggregated end-point indicators on human health and ecosystem quality, so cannot be used directly here. The greenhouse gas emissions of primary production of durum wheat was estimated at 0.80 (Barilla, 2011) and $0.84 \mathrm{~kg} \mathrm{CO}{ }_{2} \mathrm{e} / \mathrm{kg} \mathrm{NW}$ (De Cecco, 2010); which is similar to that for bread wheat in the UK (Williams et al., 2010). Ruini and Marino (2009) quoted estimates of energy in milling durum wheat for semolina for three mills, from which we have estimated greenhouse gas emissions of $0.046 \mathrm{~kg} \mathrm{CO}{ }_{2} \mathrm{e} / \mathrm{kg} \mathrm{NW}$. This is similar to Barilla (2011), but is much lower than that of De Cecco (2010) who reported that their milling extraction rate is lower than usual in order to maximise quality. Barilla (2011) and De Cecco (2010) both cited estimates of $0.27 \mathrm{~kg} \mathrm{CO}_{2} \mathrm{e} / \mathrm{kg} \mathrm{NW}$ for the production of pasta from semolina.

Ruini and Marino (2009) and Röös et al. (2011) present estimates of greenhouse gas emissions for cardboard-based packaging, however, the majority of pasta sold in the major retail outlets in the UK 
is wrapped in polypropylene film. The central estimate of packaging weight for UK-sold dry pasta is $6.3 \mathrm{~g} / \mathrm{kg}$, from which we have estimated $0.05 \mathrm{~kg} \mathrm{CO} \mathrm{CO}_{2} \mathrm{e} / \mathrm{kg} \mathrm{NW}$. Pasta is distributed to retail in ambient heavy goods vehicles therefore we assumed the same greenhouse gas emissions for distribution on a fresh weight basis as for potatoes (Tassou et al., 2008). Assuming typical distances from field to milling followed by road and ferry transportation to the RDC in the UK and an emission factor of $0.15 \mathrm{~kg} \mathrm{CO} 2 \mathrm{e} / \mathrm{t}-\mathrm{km}$ (Defra, 2014) gave a total greenhouse gas emissions of $0.33 \mathrm{~kg} \mathrm{CO} 2 \mathrm{e} / \mathrm{kg} \mathrm{NW}$ pasta (Williams et al., 2013).

Without access to the underlying data used to produce the EPDs for pasta, we could not carry out a Monte Carlo simulation of uncertainty for the greenhouse gas emissions of pasta. However, Röös et al. (2011) analysed the uncertainties for pasta production in Sweden, and estimated a coefficient of variation of $15 \%$ for primary production and $10 \%$ for the processing and delivery stages. On the basis of the EPDs of Barilla (2011) and De Cecco (2010) and our own estimates for packaging and transport, therefore we estimate a total greenhouse gas emissions of $1.4-1.7 \mathrm{~kg} \mathrm{CO}_{2} \mathrm{e} / \mathrm{kg} \mathrm{NW}$ (mean $=1.6 \mathrm{~kg} \mathrm{CO}_{2} \mathrm{e} / \mathrm{kg} \mathrm{NW}$ ) (Table 3).

\subsubsection{Rice}

A number of studies provided estimates for various stages in rice production (Table 4). However, it is difficult to make direct comparisons between them as the boundaries are inconsistent; there are differences in analytical methods and data sources (particularly, the emission factors for nitrous oxide and methane from paddy fields); and there are systematic differences between rice production areas (including soil, climate, fertiliser application rate, level of mechanisation and managerial skill). Only Pathak, et al. (2010) explicitly quantified the greenhouse gas emissions of basmati in India. Whilst levels of mechanisation and fertilisation are likely to be lower in India than in many other countries, Pathak et al. (2010) used "end of pipe" estimates for greenhouse gas emissions associated with fuel and omitted the overheads of fuel extraction and delivery. Therefore they underestimate the true life-cycle greenhouse gas emissions. We have estimated greenhouse gas emissions in primary production of $1.86 \mathrm{~kg} \mathrm{CO} 2 \mathrm{e} / \mathrm{kg} \mathrm{NW}$ for basmati (Williams, et al., 2013). Although primary production dominates, milling and drying may increase emissions by around $4 \%$ (Blengini and Busto, 2009; Yoshikawa, 2010). Based on estimated energy used in milling rice (from personal communication with an author of Kasmaprapruet et al. (2009)) and greenhouse gas emissions for Indian electricity (from Merciai et al., 2011), milling adds $0.07 \mathrm{~kg} \mathrm{CO} 2 \mathrm{e} / \mathrm{kg} \mathrm{NW}$ to the greenhouse gas emissions for basmati.

The greenhouse gas emissions associated with transport from India to RDC assumed road travel in India, container shipping to the UK; followed by road travel to a packing plant and RDC. Greenhouse gas emissions from the average heavy goods vehicle were assumed using Defra (2012). Assuming polypropylene film packaging (as for pasta), post-farm gate greenhouse gas emissions were estimated at $0.384 \mathrm{~kg} \mathrm{CO}_{2} \mathrm{e} / \mathrm{kg} \mathrm{NW}$ (Williams, et al., 2013).

Emissions for the post-agricultural stage are dominated by $\mathrm{CO}_{2}$ (Pathak et al., 2010) and are broadly analogous those in the pasta processing and distribution. Uncertainty estimates for $\mathrm{N}_{2} \mathrm{O}$ and $\mathrm{CH}_{4}$ (IPCC, 2006) were used, together with a coefficient of variation of $20 \%$ for post-harvest activity to provide an overall uncertainty range. The total greenhouse gas emissions for basmati was estimated as $1.9-2.8 \mathrm{~kg} \mathrm{CO} \mathrm{C}_{2} \mathrm{e} / \mathrm{kg} \mathrm{NW}$ (mean $=2.3 \mathrm{~kg} \mathrm{CO}{ }_{2} \mathrm{e} / \mathrm{kg} \mathrm{NW}$ ) (Table 4).

\subsection{Blue water scarcity footprint}

\subsubsection{Potatoes}

Hess et al. (2015b) estimated the blue water consumption for primary production of maincrop potatoes by region in Great Britain, which reflects the irrigation water consumed or incorporated in the product. Small volumes of blue water consumed in general farm water use and water consumption associated with inputs were considered insignificant. The average blue water 
consumption, weighted according to production and proportion of the crop that is irrigated, was 11 $\mathrm{l} / \mathrm{kg} \mathrm{NW}$, which compares well with the national average figure of $13 \mathrm{l} / \mathrm{kg}$ NW estimated by (Mekonnen and Hoekstra, 2010) for the UK. When weighted by the water stress index in the location of production, the weighted average value is $2.8 \mathrm{I} \mathrm{H} \mathrm{H}_{2} \mathrm{Oeq} / \mathrm{kg} \mathrm{NW}$ (Table 5). This was allocated between potatoes of suitable grade for packing, waste, and low grade potatoes destined for animal feed (Williams et al., 2013) giving a blue water scarcity footprint of primary production of 3.3 I $\mathrm{H}_{2} \mathrm{Oeq} / \mathrm{kg} \mathrm{NW}$. No significant volumes of water are used in potato storage or transport.

Blue water consumption, from the public water supply, was estimated from a study of a potato packing facility in Lincolnshire, UK (UoN, 2011) and estimated at $0.32 \mathrm{l} / \mathrm{kg}$ production. As the location of the potato packaging is distributed across the country, the national average water stress index for the UK has been used to weight blue water consumption giving $0.12 \mathrm{I} \mathrm{H}_{2} \mathrm{Oeq} / \mathrm{kg} \mathrm{NW}$. Based on the energy consumption estimates for storage and distribution from the greenhouse gas emissions above and unit water consumption for electricity and diesel (Pfister et al., 2011 and Gleick, 1994 respectively) the blue water consumption of energy production was $<0.2 \mathrm{l} / \mathrm{kg} \mathrm{NW}$ and has been ignored. Therefore, the average blue water consumption of British grown fresh potatoes is $13.3 \mathrm{l} / \mathrm{kg}$ NW equivalent to a blue water scarcity footprint of 3.4 I $\mathrm{H}_{2} \mathrm{Oeq} / \mathrm{kg} \mathrm{NW}$.

\subsubsection{Pasta}

Aldaya and Hoekstra (2010) estimated the irrigation water consumption for Italian durum wheat at $525 \mathrm{l} / \mathrm{kg} \mathrm{NW}$, however, they assumed that all the wheat area was irrigated and that the crop water requirements were fully satisfied (Aldaya and Hoekstra, 2009). As a winter crop, a relatively small proportion of the durum wheat crop in Italy is irrigated (Eurostat, 2013) therefore, the estimates of Aldaya and Hoekstra (2010) are unreasonable. Ruini et al. (2013) estimated blue water consumption in the production of durum wheat semolina for at $47 \mathrm{l} / \mathrm{kg} \mathrm{NW}$ but this included wheat grown imported from countries such as Mexico and USA where more durum wheat is irrigated. Mekonnen and Hoekstra (2010) used regional estimates of the proportion of the crop that is irrigated to model blue water consumption. Combining these with the area of production of durum wheat for each region of Italy (Table 6), the estimated average blue water consumption is $22.8 \mathrm{l} / \mathrm{kg} \mathrm{NW}$ and the water stress index is $21.4 \mathrm{I} \mathrm{H} \mathrm{H}_{2} \mathrm{Oeq} / \mathrm{kg} \mathrm{NW}$.

Water is an ingredient in pasta and $0.31 \mathrm{I}$ of water is added to each $\mathrm{kg}$ of wheat semolina (Bevilacqua et al., 2007). Although estimates of the water consumed in milling, production and packaging range from 3.3 (De Cecco, 2010) - 5.7 I/kg NW (Barilla, 2011), an average of $4.5 \mathrm{I} / \mathrm{kg} \mathrm{NW}$ has been assumed which is close to the estimate of (Ruini et al., 2013). A small amount of water ( $0.3 \mathrm{l} / \mathrm{kg} \mathrm{NW}$ ) is also consumed in distribution (Barilla, 2011) but water used in the generation of energy has been ignored. As the location of the pasta processing is distributed across the country, the national average water stress index for Italy has been used to estimate the blue water scarcity footprint. Therefore, the total blue water consumption of $1 \mathrm{~kg}$ pasta produced from Italian grown durum wheat is estimated at $27.4 \mathrm{l} / \mathrm{kg} \mathrm{NW}$ and the blue water scarcity footprint is $23.8 \mathrm{I} \mathrm{H}_{2} \mathrm{Oeq} / \mathrm{kg} \mathrm{NW}$.

\subsubsection{Rice}

Estimates for the blue water consumption in rice growing in Asia vary markedly between countries depending on climate and yields (Chapagain and Hoekstra, 2011; Zhang et al., 2014; Yao et al., 2013). Chapagain and Hoekstra (2011) estimated the total blue water consumption of milled rice for India at $826 \mathrm{l} / \mathrm{kg} \mathrm{NW}$, however, there are significant regional variations in blue water consumption in India due to regional variations in climate and crop yields (Kumar and Jain, 2011).

No sources of water consumption data have been found specifically for basmati. It can be assumed that blue water consumption of basmati, will be similar to other varieties of rice, however, the lower yield means that the blue water consumption is higher. The yield of basmati is typically less than that of other rice varieties. For example, in 1998/99, the average yield of basmati in the Punjab region of India was $1.2 \mathrm{t} / \mathrm{ha}$ compared to a national average rice yield of $1.9 \mathrm{t} / \mathrm{ha}$ (DRD, 2013). Therefore, the 
blue water consumption of basmati has been estimated for Indian states from the estimates for milled rice (Kampman, 2007) as follows;

$$
B W C_{i, \text { basmati }}=\frac{1.9}{1.2} B W C_{i, \text { non-basmati }}
$$

Where $B W C_{i, \text { non-basmati }}$ is the $B W C_{i}$ quoted by (Kampman, 2007) for non-basmati and 1.9/1.2 represents the relative yield of non-basmati to basmati .

Based on these and estimates of production by state, the weighted average blue water consumption is $2,407 \mathrm{l} / \mathrm{kg} \mathrm{NW}$ (Table 7). When the blue water consumption is weighted by the water stress index in the location of production, the weighted average value is $2,132 \mathrm{I} \mathrm{H}_{2} \mathrm{Oeq} / \mathrm{kg} \mathrm{NW}$. No estimates were available for water consumption after milling or distribution.

\section{Discussion}

Although similar to pasta in terms of greenhouse gas emissions per unit carbohydrate, potatoes $(0.05 \mathrm{~kg} \mathrm{CO} 2 \mathrm{e})$ have lower greenhouse gas emissions than pasta $\left(0.12 \mathrm{~kg} \mathrm{CO}_{2} \mathrm{e}\right)$ or basmati $(0.17$ $\mathrm{kg} \mathrm{CO}_{2} \mathrm{e}$ ) per portion (Table 8).

Indian basmati has the highest greenhouse gas emissions per portion due largely to the emissions associated with primary production (Figure 3a). Anaerobic conditions in paddy fields result in exacerbated methane (Misra et al., 2014) and nitrous oxide (Akiyama et al., 2005) emissions. In addition, given the large distances between the regions of $\mathrm{N}$ India where basmati is grown and the $\mathrm{RDC}$ in the UK, significant emissions are associated with transportation. Although transport distances are shorter, greater emissions are associated with processing of pasta and storage of potatoes.

The blue water consumption of British potatoes and Italian pasta are similar per portion, however, the blue water scarcity footprint of Indian basmati (Figure $3 \mathrm{~b}$ ) is two orders of magnitude greater. As this is a fully irrigated crop, it has considerably higher blue water consumption than either British potatoes or Italian pasta (which are produced from rain-fed crops or given only supplementary irrigation). The higher degree of water scarcity in the basmati producing regions of northern India (water stress index $=0.549$ ) and durum wheat growing regions of southern Italy (water stress index = 0.518 ), compared to the potato growing areas of Britain (water stress index $=0.148$ ) means that the blue water scarcity footprint of a portion of basmati $\left(160 \mid \mathrm{H}_{2} \mathrm{Oeq}\right)$ is two orders of magnitude greater than for Italian pasta $\left(1.8 \mid \mathrm{H}_{2} \mathrm{Oeq}\right)$ or British potatoes $\left(0.6 \mathrm{I} \mathrm{H}_{2} \mathrm{Oeq}\right)$. In all three cases, the largest share of the blue water consumption is at the primary production stage reflecting the water used for irrigation.

Although basmati is the most popular variety of rice with UK consumers (accounting for about 50\% of all rice sold in the UK) and has high value, the average yield per hectare is low such that its greenhouse gas emissions and blue water scarcity footprint per kg are about $60 \%$ higher than for non-basmati varieties. In the case of greenhouse gas emissions, this accounts for most of the difference compared to pasta and potatoes, however, even non-basmati rice has considerably higher blue water scarcity footprint than the alternative foods.

Combining the unit greenhouse gas emissions and blue water scarcity footprint (Table 8) with the trends in household purchases (Figure 1) allows an estimate of the change in environmental burdens associated with a change in dietary preference (Figure 4). The increased greenhouse gas emissions associated with increased household purchases of rice and pasta has been, more or less, compensated by a reduction in emissions associated with purchases of potatoes. Therefore, the net effect of the three trends is almost zero. However, increasing household purchases of rice have resulted in a large increase in blue water scarcity footprint that far outweighs the effect of reduced potato purchases. 


\section{Conclusions}

This environmental analysis compared potatoes, pasta and basmati as alternative starchy carbohydrate foods up to the point of retail in the UK. A typical portion of basmati had the highest greenhouse gas emissions $\left(0.17 \mathrm{~kg} \mathrm{CO} \mathrm{CO}_{2} \mathrm{e}\right)$ and potential impact on water scarcity $\left(160 \mathrm{I} \mathrm{H}_{2} \mathrm{Oeq}\right)$ compared with British potatoes $\left(0.05 \mathrm{~kg} \mathrm{CO}_{2} \mathrm{e}, 0.6 \mathrm{I} \mathrm{H} \mathrm{H}_{2} \mathrm{Oeq}\right)$ or Italian pasta $\left(0.12 \mathrm{~kg} \mathrm{CO}{ }_{2} \mathrm{e}, 1.8 \mathrm{I}\right.$ $\mathrm{H}_{2} \mathrm{Oeq}$ ) mainly as a consequence of increased methane emissions from anaerobic rice paddies, long delivery distances and the concentration of basmati production in an area of higher water scarcity. Therefore the trend towards increased per capita purchases of rice and reduction in fresh potatoes seen in the UK over the last three decades has increased the per capita environmental burdens, but in particular the potential impact on water scarcity. The substitution of rice and pasta for potatoes in the British diet not only results in a greater impact on global water resources, but also relocates that impact from the UK to $\mathrm{N}$ India or Italy.

Food consumption is a major contributor to the national greenhouse gas emissions and blue water scarcity footprint, and the dietary choices of individuals have an important influence on these environmental burdens (Hallström et al., 2015). Several have argued that changing what we eat is an important component of reducing greenhouse gas emissions (e.g., Garnett, 2014; Bajzelj et al., 2014) and an individual's blue water scarcity footprint (Hess, et al., 2015a) but most attempts to quantify the impact have focussed on substituting meat-based foods for plant-based foods in the diet. Here we have shown that dietary choices within food groups (in this case starchy carbohydrates) can significantly affect not only the overall environmental impact of food consumption, but also the geographical location of that impact. Although consumers rarely make food purchasing decisions on the basis of environmental impacts (Cohen and Babey, 2012) we have shown that the life cycle approach taken here lends itself to understanding where the impacts occur and thus informs those in the supply chain about where efforts should be targeted to reduce those impacts. Coupling water and greenhouse gas emissions shows the benefit of not relying on a single environmental indicator.

\section{Acknowledgement}

The authors thank Potato Council (a division of the Agriculture \& Horticulture Development Board) for supporting this work and for the provision of statistical data on potato production in Great Britain. 


\section{References}

ADAS, Serio, EuGeos Limited and CFI Sheffield Hallam University (2012). Final Report of project FO0412 to DEFRA

http://randd.defra.gov.uk/Default.aspx?Menu=Menu\&Module=More\&Location=None\&ProjectID=1 6390\&FromSearch=Y\&Status=3\&Publisher $=1 \&$ SearchText=FO0412\&SortString=ProjectCode\&SortOr der=Asc\&Paging=10\#Description. (accessed 18 Nov 14.).

AIREA (2014) Rice production statistics. All India Rice Exporters Association.

http://www.airea.net/page/60/statistical-data/state-wise-basmati-rice-production. Accessed 10 November 2014.

Akiyama, $\mathrm{H}$; Yagi, K; Yan, $\mathrm{XY}$ (2005) Direct $\mathrm{N}_{2} \mathrm{O}$ emissions from rice paddy fields: Summary of available data. Global Biogeochemical Cycles, 19(1):1-10.

Aldaya, M. M. and Hoekstra, A. Y. (2009) The water needed to have Italians eat pasta and pizza. Value of Water. Research Report Series No. 36. Water Footprint Network, The Netherlands.

Aldaya, M. M. and Hoekstra, A. Y. (2010), The water needed for Italians to eat pasta and pizza, Agricultural Systems, 103:351-360.

Bajželj, B., Richards, K.S., Allwood, J.M., Smith, P., Dennis, J.S. Curmi, E. and Gilligan, C.A. (2014) Importance of food-demand management for climate mitigation. Nature Climate Change, 2014(4):924-929.

Barilla (2011) Environmental Product Declaration of durum wheat semolina dried Pasta in paperboard box (brand Barilla). Revision 2.1. March 2011.

http://gryphon.environdec.com/data/files/6/7968/epd217_rev2.1.pdf. Last accessed 18 Nov 2014.

Bevilacqua, M., Braglia, M., Carmignani, G. and Zammori, F. A. (2007) Life cycle assessment of pasta production in Italy. Journal of Food Quality, 30(6): 932-952.

Blengini, G. A. and Busto, M. (2009) The life cycle of rice: LCA of alternative agri-food chain management systems in Vercelli (Italy), Journal of Environmental Management, 90(3): 1512-1522.

Brodt, S., Kendall, A., Lee, I., Yuan, J., Thompson, J., Feenstra, G. (2009) Life Cycle Assessment of Greenhouse Gas Emissions in California Rice Production and Processing Systems. In 'Life Cycle Assessment IX' toward the global life cycle economy' Boston, September 29th - October 2nd, 2009

Brodt, S., Kramer, K.J., Kendall, A., Feenstra, G. (2013) Comparing environmental impacts of regional and national-scale food supply chains: A case study of processed tomatoes. Food Policy, 42:106-114.

BSI (2008) PAS 2050:2008: Specification for the assessment of the life cycle greenhouse gas emissions of goods and services. BSI Group and Carbon Trust. ISBN 978-0-580-64636-2.

Carlsson-Kanyama, A. (1998) Climate change and dietary choices - how can emissions of greenhouse gases from food consumption be reduced?. Food Policy, 23: 277-293.

Chapagain, A. K. and Hoekstra, A. Y. (2011) The blue, green and grey water footprint of rice from production and consumption perspectives. Ecological Economics, 70(4): 749-758.

Cohen, D. A. and Babey, S. H. (2012) Contextual influences on eating behaviours: heuristic processing and dietary choices. Obesity Reviews, 13: 766-779.

De Cecco (2010) Environmental Product Declaration De Cecco durum wheat semolina pasta. http://gryphon.environdec.com/data/files/6/8231/epd282en.pdf. Last accessed 18 Nov 2014.

Defra (2008) Understanding the GHG impacts of food preparation and consumption in the home. Final report on project FO0406. http://tinyurl.com/Defra-FO0406. Last accessed 18-Nov-14. 
Defra (2009a) Scenario building to test and inform the development of a BSI method for assessing GHG emissions from food. Final report on Project FO0404. http://tinyurl.com/Defra-FO0404. Last accessed 18-Nov-14.

Defra (2009b) Greenhouse gas impacts of food retailing. Final report on project FO0405 http://tinyurl.com/Defra-FO0405. Last accessed 18-Nov-14.

Defra (2012) Government conversion factors for company reporting. http://www.ukconversionfactorscarbonsmart.co.uk/. Last accessed 18-Nov-14.

Defra (2012) Family food datasets. https://www.gov.uk/government/statistical-data-sets/familyfood-datasets. Family food datasets. https://www.gov.uk/government/statistical-data-sets/familyfood-datasets. Last accessed 18 Nov 2014.

DRD (2013) Directorate of Rice Development. http://drd.dacnet.nic.in/. Last accessed 18-Nov-14.

Ecoinvent (2014) http://www.ecoinvent.org/database/ecoinvent-version-2/. Last accessed 18-Nov14.

Eurostat (2013) Agricultural Production Statistics. http://epp.eurostat.ec.europa.eu/portal/page/portal/agriculture/data/database. Last accessed 18Nov-14.

Falkenmark, M. (1995) Land-water linkages: a synopsis, in Mather, T. H. (ed.) FAO Land and Water Bulletin No. 1. Land and water integration and river basin management, Food and Agriculture Organisation, Rome, Italy, pp. 15-16.

Food Standards Agency (2002) McCance and Widdowson's the Composition of Foods, Summary Edition (6th Edition). Cambridge: Royal Society of Chemistry. ISBN: 978-0-85404-428-3.

Forster, P., Ramaswamy, V., Artaxo, P., Berntsen, T., Betts, R., Fahey, D.W., Haywood, J., Lean, J., Lowe, D.C., Myhre, G., Nganga, J., Prinn, R., Raga, G., Schulz, M. and van Dorland, R. (2007) Changes in atmospheric constituents and in radiative forcing. In: Solomon, S., Qin, D., Manning, M., Chen, Z., Marquis, M., Averyt., K.B., Tignor, M. and Miller, H.L. (eds) Climate Change 2007: The Physical Science Basis. Contribution of Working Group I to the Fourth Assessment Report of the Intergovernmental Panel on Climate Change. Cambridge University Press, Cambridge, United Kingdom and New York, NY, USA

Garnett, T. (2011) Where are the best opportunities for reducing greenhouse gas emissions in the food system (including the food chain)? Food Policy, 36 (SUPPL. 1), pp. S23-S32.

Garnett, T. (2014) Three perspectives on sustainable food security: Efficiency, demand restraint, food system transformation. What role for life cycle assessment? Journal of Cleaner Production, 73:10-18.

Gleick, P.H. (1994) Water and energy. Annual Review of Energy and the Environment 19, 267e299.

Hager, T. J. and Morawicki, R. (2013), Energy consumption during cooking in the residential sector of developed nations: A review, Food Policy, 40: 54-63.

Hallström, E., Carlsson-Kanyama, A. and Börjesson, P. (2015) Environmental impact of dietary change: a systematic review. Journal of Cleaner Production, 91: 1-11.

Hess, T.M., Aldaya, M., Fawell, J., Franceschini, H., Ober, E., Schaub, R. and Schulze-aurich, J. (2014) Understanding the impact of crop and food production on the water environment - Using sugar as a model. Journal of the Science of Food and Agriculture, 94(1): 2-8.

Hess, T.M., Andersson, U., Mena, C. and Williams, A. (2015a) The impact of healthier dietary scenarios on the global blue water scarcity footprint of food consumption in the UK. Food Policy, 50 : 1-10. 
Hess, T.M., Lennard, A.T. and Daccache, A. (2015b) Comparing local and global water scarcity information in determining the water scarcity footprint of potato cultivation in Great Britain. Journal of Cleaner Production. 87: 666-674.

Hoekstra, A. Y. and Chapagain, A. K. (2007) Water footprints of nations: Water use by people as a function of their consumption pattern. Water Resources Management, 21(1): 35-48.

Hoekstra, A. Y., Chapagain, A. K., Aldaya, M. M. and Mekonnen, M. M. (2011) The water footprint assessment manual. Setting the global standard. Earthscan, London.

Hokazono, S., Hayashi, K. (2012) Variability in environmental impacts during conversion from conventional to organic farming: a comparison among three rice production systems in Japan. Journal of Cleaner Production, 28: 101-112.

ISO (2014), Environmental management - Water footprint - Principles, requirements and guidelines. ISO 14046. International Organization for Standardization., Geneva, Switzerland.

JRC (2013) European Platform on Life Cycle Assessment. http://eplca.jrc.ec.europa.eu/. Last accessed 4-Nov-14.

Kampman, D.A. (2007) The water footprint of India. A study on water use in relation to the consumption of agricultural goods in the Indian states. MSc thesis. University of Twente, The Netherlands.

Kasmaprapruet, S., Paengjuntuek, W., Saikhwan, P. (2009) Life Cycle Assessment of Milled Rice Production: Case Study in Thailand. European Journal of Scientific Research, 30 (2): 195-203

Kounina, A., Margni, M., Bayart, J. -., Boulay, A. -., Berger, M., Bulle, C., Frischknecht, R., Koehler, A., Milà I Canals, L., Motoshita, M., Núñez, M., Peters, G., Pfister, S., Ridoutt, B., Van Zelm, R., Verones, F. and Humbert, S. (2013) Review of methods addressing freshwater use in life cycle inventory and impact assessment. International Journal of Life Cycle Assessment, 18: 707-721.

Kumar, V. and Jain, S. K. (2011), Export and import of virtual water from different states of India through food grain trade. Hydrology Research, 42: 229-238.

Lewis, H.B., Ahern, A.L. and Jebb, S.A. (2012) How much should I eat? A comparison of suggested portion sizes in the UK. Public Health Nutrition, 15(11): 2110-2117.

Mekonnen, M. M. and Hoekstra, A. Y. (2010) The green, blue and grey water footprint of crops and derived crop products. UNESCO-IHE, Delft, the Netherlands.

Mekonnen, M. M. and Hoekstra, A. Y. (2011) The green, blue and grey water footprint of crops and derived crop products. Hydrology and Earth System Sciences, 15: 1577-1600.

Mekonnen, M. M. and Hoekstra, A. Y. (2012) A Global Assessment of the Water Footprint of Farm Animal Products. Ecosystems, 15: 401-415.

Merciai, S., Schmidt, J.H. and Dalgaard, R. (2011) Inventory of country specific electricity in LCA - India. Inventory report v2. 2.-0 LCA consultants, Aalborg. http://www.Icanet.com/projects/electricity_in_Ica/. Last accessed 18 Nov 2014.

Mills, H. and Patel, S. (2002) Food portion sizes. Food Standards Agency. 2002.

Misra, A.K., Verma, M. (2014) Modeling the impact of mitigation options on methane abatement from rice fields. Mitigation and Adaptation Strategies for Global Change, 19: 927-945.

Verain, M.C.D., Dagevos, H. and Antonides, G. (2015) Sustainable food consumption. Product choice or curtailment?, Appetite 91: 375-384. 
Nemecek, T., Weiler, K., Plassmann, K. (2012) Estimation of the variability in global warming potential of worldwide crop production using a modular extrapolation approach. Journal of Cleaner Production, 31: 106-117.

Pathak, H., Jain, N., Bhatia, A., Patel, J. and Aggarwal, P.K. (2010) Carbon footprints of Indian food items. Agriculture Ecosystems \& Environment, 139: 66-73.

PCL (2012) Consumption and Processing in GB. Annual Trends 1988 - 2012.

http://www.potato.org.uk/publications/consumption-and-processing-gb-annual-trends-1988-2012. Last accessed 18 Nov 2014.

Pfister, S., Koehler, A. and Hellweg, S. (2009) Assessing the environmental impacts of freshwater consumption in LCA. Environmental Science and Technology, 43: 4098-4104.

Pfister, S., Saner, D. and Koehler, A. (2011) The environmental relevance of freshwater consumption in global power production. International Journal of Life Cycle Assessment, 16: 580-591.

Pfitzer S. (2014) www.ifu.ethz.ch/staff/stpfiste/Impact_factors_LCA_pfister_et_al.kmz. Last accessed 18 Nov 2014.

Renault, D. and Wallender, W.W. (2000) Nutritional water productivity and diets. Agricultural Water Management, 45: 275-296.

Ridoutt, B. G. and Pfister, S. (2010) A revised approach to water footprinting to make transparent the impacts of consumption and production on global freshwater scarcity. Global Environmental Change-Human and Policy Dimensions, 20: 113-120.

Ridoutt, B. G., Juliano, P., Sanguansri, P. and Sellahewa, J. (2010) The water footprint of food waste: case study of fresh mango in Australia, Journal of Cleaner Production, 18: 1714-1721.

Ridoutt, B.G., Page, G., Opie, K., Huang, J., Bellotti, W. (2014) Carbon, water and land use footprints of beef cattle production systems in southern Australia. Journal of Cleaner Production, 73: 24-30.

Röös, E., Sundberg, C \& Hansson, P-A. (2010) Uncertainties in the carbon footprint of food products: a case study on table potatoes. International Journal of Life Cycle Assessment, 15: 478-488.

Röös, E., Sundberg, C., Hansson, P-A. (2011) Uncertainties in the carbon footprint of refined wheat products: a case study on Swedish pasta. International Journal of Life Cycle Assessment, 16: 338-350.

Ruini, L. and Marino, M. (2009) LCA of semolina dry pasta produced by Barilla. Presented at "Sustainable development: a challenge for European research; Brussels, 26-28 May 2009" http://ec.europa.eu/research/sd/conference/2009/papers/3/massimo_marino_-_lca_barilla.pdf

Ruini, L., Marino, M., Pignatelli, S., Laio, F. and Ridolfi, L. (2013) Water footprint of a large-sized food company: The case of Barilla pasta production. Water Resources and Industry, 1-2: 7-24.

Schenker, S. (2012) An overview of the role of rice in the UK diet. Nutrition Bulletin, 37: 309-323.

Supakornchuwong, C. and Suwannaporn, P. (2012) Attitudes toward rice compared with potatoes and pasta among British, French, Dutch and Belgian consumers. Journal of Sensory Studies, 27: 7177.

Tassou, S., Ge, Y., Hadawey, A., Marriott, D. (2008) Greenhouse Gas Impacts of Food Retailing. Final report to Defra on project FO0405. http://tinyurl.com/Defra-FO0405. Last accessed 18 Nov 2014.

Tilda (2014) Why Basmati is Best. http://www.tilda.com/our-rice/why-basmati-is-best. Last accessed 18 Nov 2014.

UoN (2011) Water Balance of Potato Processing at Branston's Lincoln Site. University of Northampton. 
Vanham, D., Mekonnen, M.M. and Hoekstra, A.Y. (2013). The water footprint of the EU for different diets. Ecological Indicators, 32: 1-8.

Webb, J., Williams, A.G., Hope, E., Evans, D. and Moorhouse, E. (2013) Do foods imported into the UK leave a greater environmental footprint than the same foods produced within the UK? International Journal of Life Cycle Assessment, 18: 1325-1343.

Weichselbaum, E. (2010) An overview of the role of potatoes in the UK diet. Nutrition Bulletin, 35: 195-206.

Williams, A.G., Audsley, E. \& Sandars, D.L. (2006) Final report to Defra on project IS0205: Determining the environmental burdens and resource use in the production of agricultural and horticultural commodities. London: Defra.

http://randd.defra.gov.uk/Document.aspx?Document=IS0205_3959_FRP.doc. Last accessed 18 Nov 2014.

Williams, A.G., Audsley, E. and Sandars, D.L. (2010) Environmental burdens of producing bread wheat, oilseed rape and potatoes in England and Wales using simulation and system modelling The International Journal of Life Cycle Assessment, 15: 855-868.

Williams, A.G., Hess, T.M., Chatterton, J. and Daccache, A. (2013) Are potatoes a low-impact food for GB consumers compared with rice and pasta? The Potato Council, Stoneleigh, UK. April 2013.

Wiltshire, J, Tucker, G, Williams, AG, Foster, C, Wynn, S, Thorn, R and D Chadwick (2009) Scenario building to test and inform the development of a BSI method for assessing GHG emissions from food. Final report to Defra on research project FO0404, London. http://tinyurl.com/Defra-FO0404

WRAP (2011) Mapping fruit and vegetable waste through the retail and wholesale supply chain. Project code: RSC008. June 2011.

http://www.wrap.org.uk/sites/files/wrap/Resource_Map_Fruit_and_Veg_final_6_june_2011.fc479c 40.10854.pdf. Last accesed 18 Nov 2014.

Wrieden, W. L. and Barton, K.L. (2006) Calculation and collation of typical food portion sizes for adults aged 19-64 and older people aged 65 and over. Final Technical Report to the Food Standards Agency. Project number: N08026. Table 2. http://www.foodbase.org.uk/results.php?f_report_id=82. Last accessed 25-Apr-2013

Yao, P., Shyu, G., Cheng, B., Chang, Y. and Chang, T. (2013) The water footprints of rice in Taiwan. Journal of Taiwan Agricultural Engineering, 59: 1-12.

Yoshikawa, Naoki (2010) Carbon footprint estimation and data sampling method: a case study of ecologically cultivated rice produced in Japan. Proceedings of LCA food 2010. 1: 114-119

Zhang, L. J., Yin, X. A., Zhi, Y. and Yang, Z. F. (2014) Determination of virtual water content of rice and spatial characteristics analysis in China. Hydrology and Earth System Sciences, 18: 2103-2111.

Zhuo, L., Mekonnen, M. M. and Hoekstra, A. Y. (2014) Sensitivity and uncertainty in crop water footprint accounting: A case study for the Yellow River basin. Hydrology and Earth System Sciences, vol. 18, no. 6, pp. 2219-2234. 


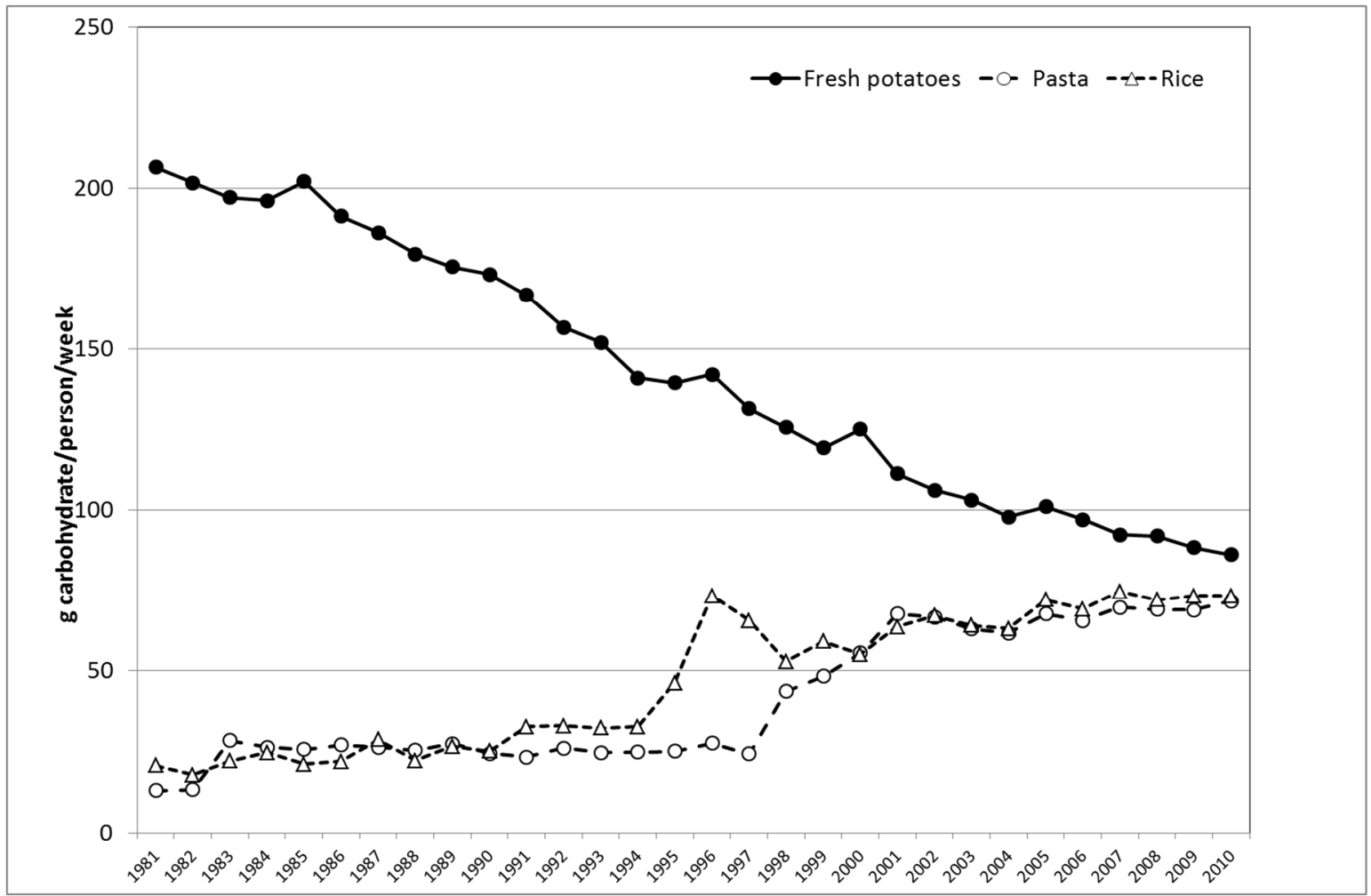

Figure 1 Trend in UK household purchases of potatoes, pasta and rice (expressed as $\mathrm{g}$ carbohydrate/person/week) 1981 - 2010 (after Defra, 2013). 


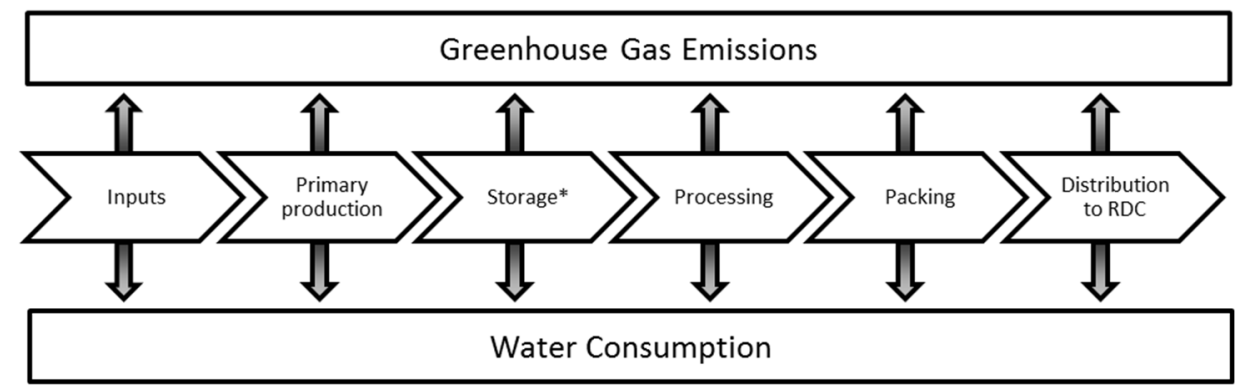

* Potatoes only

Figure 2 Scope of the life cycle assessment of greenhouse gas emissions and water consumption of potatoes, pasta and basmati rice showing stages considered. 
a) Greenhouse gas emissions

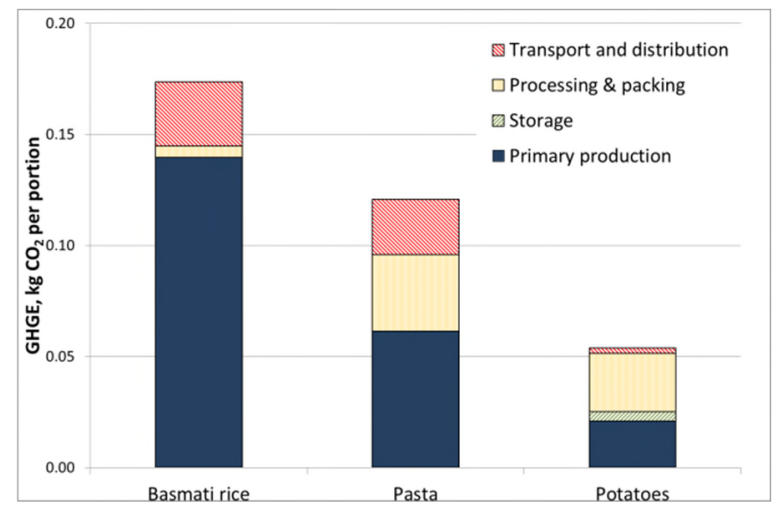

b) Blue water scarcity footprint

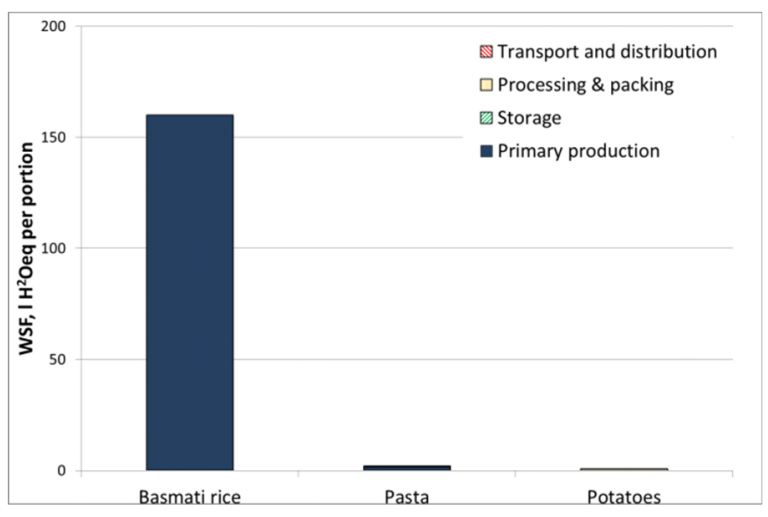

Figure 3 Summary of a) greenhouse gas emissions and b) blue water scarcity footprint of British fresh potatoes, Italian dried pasta and Indian basmati rice per portion by stage of production. 


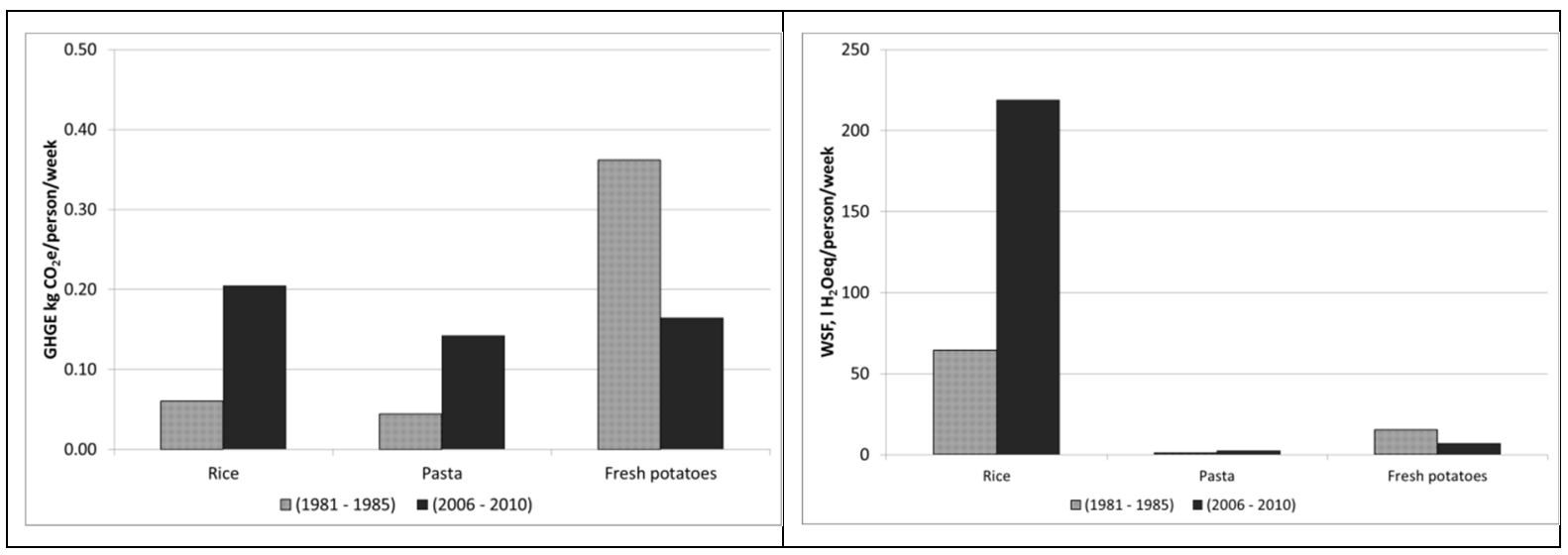

Figure 4 Change in a) greenhouse gas emissions and b) blue water scarcity footprint from household purchases of British fresh potatoes, Italian dried pasta and Indian basmati rice between 1981-85 and 200610. 
Table 1 Dry weight, carbohydrate content and assumed portion sizes of British fresh potatoes, Italian dried pasta and Indian basmati rice (after Food Standards Agency, 2002 and Lewis et al., 2012).

\begin{tabular}{lccc}
\hline & $\begin{array}{c}\text { Dry matter, } \\
\text { g/100g NW }\end{array}$ & $\begin{array}{c}\text { Carbohydrate, } \\
\text { g/100g NW }\end{array}$ & $\begin{array}{c}\text { Portion size of } \\
\text { raw foods, g NW }\end{array}$ \\
\hline Potatoes & 21 & 17.2 & 175 \\
Pasta & 90 & 75.8 & 75 \\
Rice & 90 & 79.8 & 75 \\
\hline
\end{tabular}


Table 2 Estimated greenhouse gas emissions for British fresh potatoes $\left(\mathrm{kg} \mathrm{CO}_{2} \mathrm{e} / \mathrm{kg} \mathrm{NW}\right)$ according to stage of production, from primary production to regional distribution centre (RDC).

\begin{tabular}{|c|c|c|c|c|c|c|}
\hline \multirow[t]{2}{*}{ Source } & \multirow[t]{2}{*}{ Notes } & \multicolumn{5}{|c|}{ Greenhouse gas emissions, $\mathbf{k g ~} \mathrm{CO}_{2} \mathrm{e} / \mathrm{kg} \mathrm{NW}$} \\
\hline & & $\begin{array}{l}\text { Primary } \\
\text { production }\end{array}$ & Storage & $\begin{array}{l}\text { Grading and } \\
\text { packing }\end{array}$ & $\begin{array}{l}\text { Transport to } \\
\text { RDC }\end{array}$ & $\begin{array}{l}\text { All stages } \\
\text { to RDC }\end{array}$ \\
\hline \multirow{2}{*}{$\begin{array}{l}\text { Williams at al. } \\
\text { (2006) }\end{array}$} & Maincrop & 0.17 & 0.04 & & & \\
\hline & $1^{\text {st }}$ Earlies & 0.32 & 0 & & & \\
\hline \multirow{2}{*}{$\begin{array}{l}\text { Williams at al. } \\
\text { (2010) }\end{array}$} & Maincrop & 0.13 & 0.04 & & & \\
\hline & $1^{\text {st }}$ Earlies & 0.29 & 0 & & & \\
\hline \multirow{2}{*}{$\begin{array}{l}\text { Webb et al. } \\
\text { (2013). }\end{array}$} & Maincrop & 0.11 & \multicolumn{3}{|c|}{0.17} & 0.28 \\
\hline & Earlies & 0.21 & & \multicolumn{2}{|c|}{0.08} & 0.29 \\
\hline $\begin{array}{l}\text { Wiltshire et } \\
\text { al. (2009) }\end{array}$ & Maincrop & 0.10 & 0.06 & & & \\
\hline \multirow[t]{2}{*}{$\begin{array}{l}\text { ADAS et al. } \\
(2012)\end{array}$} & $\begin{array}{l}\text { Maincrop in } \\
\text { September }\end{array}$ & & & & & 0.2 \\
\hline & $\begin{array}{l}\text { Maincrop in } \\
\text { April }\end{array}$ & & & & & 0.3 \\
\hline $\begin{array}{l}\text { Assumed } \\
\text { value }\end{array}$ & & 0.12 & 0.023 & 0.15 & 0.014 & 0.31 \\
\hline
\end{tabular}

Note: Not all studies considered every stage 
Table 3 Estimated greenhouse gas emissions for Italian pasta ( $\mathrm{kg} \mathrm{CO}_{2} \mathrm{e} / \mathrm{kg} \mathrm{NW}$ ) according to stage of production, from primary production regional distribution centre (RDC).

\begin{tabular}{|l|l|c|c|c|c|c|c|}
\hline \multirow{2}{*}{ Source } & \multirow{2}{*}{ Notes } & \multicolumn{5}{|c|}{ Greenhouse gas emissions, kg CO2e/kg NW } \\
\cline { 2 - 7 } & & $\begin{array}{c}\text { Primary } \\
\text { production }\end{array}$ & Milling & $\begin{array}{c}\text { Pasta } \\
\text { production }\end{array}$ & Packaging & $\begin{array}{c}\text { Transport to } \\
\text { RDC }\end{array}$ & $\begin{array}{c}\text { All stages } \\
\text { to RDC }\end{array}$ \\
\hline $\begin{array}{l}\text { Barilla } \\
(2011)\end{array}$ & EPD & 0.80 & 0.046 & 0.27 & 0.13 & 0.082 & 1.33 \\
\hline $\begin{array}{l}\text { De Cecco } \\
(2010)\end{array}$ & EPD & 0.84 & 0.22 & 0.27 & 0.096 & 0.057 & 1.49 \\
\hline $\begin{array}{l}\text { Own } \\
\text { estimates }\end{array}$ & & & & & 0.05 & 0.33 & \\
\hline $\begin{array}{l}\text { Assumed } \\
\text { values }\end{array}$ & & $\mathbf{0 . 8 2}$ & $\mathbf{0 . 1 4}$ & $\mathbf{0 . 2 7}$ & $\mathbf{0 . 0 5}$ & $\mathbf{0 . 3 3}$ & $\mathbf{1 . 6}$ \\
\hline
\end{tabular}

Note: Not all studies considered every stage 
Table 4 Estimated greenhouse gas emissions for Indian basmati rice $\left(\mathrm{kg} \mathrm{CO}_{2} \mathrm{e} / \mathrm{kg} \mathrm{NW}\right)$ at regional distribution centre (RDC).

\begin{tabular}{|c|c|c|c|c|c|c|c|}
\hline \multirow[b]{2}{*}{ Source } & \multirow[b]{2}{*}{$\begin{array}{l}\text { Country of } \\
\text { production }\end{array}$} & \multirow[b]{2}{*}{ Notes } & \multicolumn{5}{|c|}{ Greenhouse gas emissions, $\mathrm{kg} \mathrm{CO}_{2} \mathrm{e} / \mathrm{kg} \mathrm{NW}$} \\
\hline & & & $\begin{array}{c}\text { Primary } \\
\text { producti } \\
\text { on }\end{array}$ & $\begin{array}{c}\text { Drying, } \\
\text { milling } \\
\text { or } \\
\text { polishing }\end{array}$ & $\begin{array}{l}\text { Refining } \\
\text { and } \\
\text { packing }\end{array}$ & $\begin{array}{c}\text { Transport } \\
\text { to RDC }\end{array}$ & $\begin{array}{c}\text { All } \\
\text { stage } \\
\text { s to } \\
\text { RDC }\end{array}$ \\
\hline \multirow{3}{*}{$\begin{array}{l}\text { Blengini and } \\
\text { Busto, } 2009\end{array}$} & \multirow{3}{*}{ Italy } & $\begin{array}{r}\text { Polished, } \\
\text { conventional }\end{array}$ & 2.37 & 0.09 & 0.13 & $0.17^{(1)}$ & 2.76 \\
\hline & & Organic & & & & & 3.12 \\
\hline & & Upland & & & & & 1.24 \\
\hline $\begin{array}{l}\text { Brodt et al. } \\
\text { (2009) }\end{array}$ & USA & $\begin{array}{r}\text { Milled, } 90 \% \\
\text { white, } 10 \% \\
\text { brown }\end{array}$ & \multicolumn{2}{|c|}{1.9} & & & \\
\hline $\begin{array}{l}\text { Carlsson- } \\
\text { Kanyama, } \\
1998\end{array}$ & Unclear & $\begin{array}{r}\text { As consumed in } \\
\text { Sweden }\end{array}$ & & & & & $3.9^{(2)}$ \\
\hline \multirow{2}{*}{$\begin{array}{l}\text { Hokazono \& } \\
\text { Hayashi } \\
\text { (2012) }\end{array}$} & \multirow{2}{*}{ Japan } & $\begin{array}{r}\text { Brown, } \\
\text { conventional }\end{array}$ & \multicolumn{2}{|c|}{1.5} & & & \\
\hline & & Brown, Organic & \multicolumn{2}{|c|}{2.0} & & & \\
\hline $\begin{array}{l}\text { Kasmaprapru } \\
\text { et al. (2009) }\end{array}$ & Thailand & $\begin{array}{r}\text { Milled rice at } \\
\text { mill. }\end{array}$ & \multicolumn{2}{|c|}{2.9} & & & \\
\hline $\begin{array}{l}\text { Nemecek et } \\
\text { al. (2012) }\end{array}$ & World & $\begin{array}{r}\text { Farm gate } \\
\text { values, world } \\
\text { data }\end{array}$ & $2.4^{(3)}$ & & & & \\
\hline \multirow{2}{*}{$\begin{array}{l}\text { Pathak at al. } \\
\text { (2010) }\end{array}$} & India & $\begin{array}{l}\text { Rice, non- } \\
\text { Basmati }{ }^{(4)}\end{array}$ & 1.22 & 0 & & & \\
\hline & India & Rice, basmati & 1.52 & 0 & & & \\
\hline $\begin{array}{l}\text { Yoshikawa } \\
(2010)\end{array}$ & Japan & $\begin{array}{r}\text { Polished, } \\
\text { Organic }\end{array}$ & 1.25 & 0.05 & & 0.03 & 1.33 \\
\hline $\begin{array}{l}\text { Assumed } \\
\text { value }\end{array}$ & & & 1.86 & 0.07 & \multicolumn{2}{|c|}{0.384} & 2.31 \\
\hline
\end{tabular}

(1) To retail not just RDC

(2) Interpreted from data based on 20 year GWP not the usual 100

(3) Range 1.7 to 2.9

(4) Includes both polished (white) and brown rice 
Table 5 Regional blue water scarcity footprint of British fresh potatoes, I $\mathrm{H}_{2} \mathrm{Oeq} / \mathrm{kg} \mathrm{NW}$, weighted by production.

\begin{tabular}{|c|c|c|c|c|}
\hline Region & $\begin{array}{l}\text { Blue water consumption }{ }^{\dagger}, \\
\qquad / / k g ~ N W\end{array}$ & $\begin{array}{l}\text { Water stress } \\
\text { index }\end{array}$ & $\begin{array}{c}\text { Blue water scarcity } \\
\text { footprint } \\
\text { I } \mathrm{H}_{2} \mathrm{Oeq} / \mathrm{kg} \mathrm{NW}\end{array}$ & $\begin{array}{c}\text { Productio } \\
\mathrm{n}^{*}, \\
\text { Mt/year }\end{array}$ \\
\hline East Midlands & 10.4 & 0.139 & 2.4 & 0.81 \\
\hline East of England & 19.5 & 0.164 & 5.3 & 1.65 \\
\hline North East & 5.7 & 0.120 & 1.1 & 0.06 \\
\hline North West & 1.9 & 0.667 & 2.1 & 0.27 \\
\hline Scotland & 4.2 & 0.017 & 0.1 & 0.83 \\
\hline South East & 16.8 & 0.366 & 10.2 & 0.16 \\
\hline South West & 2.7 & 0.040 & 0.2 & 0.33 \\
\hline Wales & 5.7 & 0.088 & 0.8 & 0.08 \\
\hline West Midlands & 9.3 & 0.098 & 1.5 & 0.77 \\
\hline $\begin{array}{l}\text { Yorkshire and the } \\
\text { Humber }\end{array}$ & 7.4 & 0.140 & 1.7 & 0.73 \\
\hline Weighted average & 10.8 & 0.148 & 2.8 & 5.68 \\
\hline
\end{tabular}

+ Hess et al. (2015b)

* PCL (2012) 
Table 6 Regional blue water scarcity footprint of durum wheat in Italy, I $\mathrm{H}_{2} \mathrm{Oeq} / \mathrm{kg} \mathrm{NW}$, weighted by area of production.

\begin{tabular}{|c|c|c|c|c|}
\hline Region & $\begin{array}{l}\text { Blue water consumption }{ }^{+} \text {, } \\
\qquad / / \mathrm{kg} \mathrm{NW}^{-}\end{array}$ & $\begin{array}{l}\text { Water stress } \\
\text { index }\end{array}$ & $\begin{array}{c}\text { Blue water scarcity } \\
\text { footprint } \\
\text { I } \mathrm{H}_{2} \text { Oeq / kg NW }\end{array}$ & $\begin{array}{l}\text { Area*, } \\
\text { ha }\end{array}$ \\
\hline Abruzzo & 10.3 & 0.188 & 3.2 & 30,660 \\
\hline Basilicata & 15.6 & 0.499 & 13.0 & 136,334 \\
\hline Calabria & 16.8 & 0.604 & 16.8 & 41,085 \\
\hline Campania & 10.8 & 0.656 & 11.7 & 54,369 \\
\hline Emilia-Romagna & 23.5 & 0.103 & 4.0 & 70,486 \\
\hline Lazio & 11.0 & 0.286 & 5.2 & 53,398 \\
\hline Molise & 10.8 & 0.299 & 5.4 & 53,048 \\
\hline Puglia & 42.4 & 0.639 & 45.1 & 342,501 \\
\hline Sardegna & 28.8 & 0.150 & 7.2 & 43,562 \\
\hline Sicilia & 16.8 & 0.822 & 22.9 & 284,094 \\
\hline Toscana & 7.6 & 0.063 & 0.8 & 102,851 \\
\hline Umbria & 9.7 & 0.085 & 1.4 & 22,482 \\
\hline $\begin{array}{l}\text { Weighted } \\
\text { Average }\end{array}$ & 22.8 & 0.518 & 21.4 & $\begin{array}{c}1,234,8 \\
67\end{array}$ \\
\hline
\end{tabular}

+ Mekonnen and Hoekstra (2010). Blue water consumption was not available for Sicilia, so the value for Calabria has been used.

* Area of durum wheat production (2010) http://www.istat.it. No estimates of production by region were available, so area has been used as a surrogate. 
Table 7 Regional blue water scarcity footprint of basmati rice in India, I $\mathrm{H}_{2} \mathrm{Oeq} / \mathrm{kg} \mathrm{NW}$, weighted by production.

\begin{tabular}{|l|c|c|c|c|}
\hline Region & $\begin{array}{c}\text { Blue water } \\
\text { consumption }{ }^{\dagger}, \mathbf{I} / \mathbf{k g} \\
\mathbf{N W}\end{array}$ & $\begin{array}{c}\text { Water stress } \\
\text { index }\end{array}$ & $\begin{array}{c}\text { Blue water scarcity } \\
\text { footprint } \\
\text { I H2Oeq/kg NW }\end{array}$ & $\begin{array}{c}\text { Production } \\
\text { * } \\
\text { Mt/year }\end{array}$ \\
\hline Delhi & 6,178 & 0.462 & 4741 & 0.006 \\
\hline Haryana & 3,369 & 0.486 & 2722 & 2.426 \\
\hline Himachal Pradesh & 654 & 0.538 & 585 & 0.006 \\
\hline $\begin{array}{l}\text { Jammu and } \\
\text { Kashmir }\end{array}$ & 2,801 & 0.548 & 2548 & 0.139 \\
\hline Punjab & 2,164 & 0.564 & 2026 & 2.723 \\
\hline Uttar Pradesh & 1,444 & 0.615 & 1476 & 1.753 \\
\hline Uttaranchal & 1,444 & 0.478 & 1146 & 0.058 \\
\hline $\begin{array}{l}\text { Weighted } \\
\text { Average }\end{array}$ & $\mathbf{2 , 4 0 7}$ & $\mathbf{0 . 5 4 9}$ & $\mathbf{2 , 1 3 2}$ & 7.111 \\
\hline
\end{tabular}

${ }^{+}$after Kampman (2007)

* All India Rice Exporters Association (AIREA, 2014) 
Table 8 Summary of greenhouse gas emissions and blue water scarcity footprint of British potatoes, Italian pasta and Indian basmati rice at the point of retail. Results are presented on the basis of weight of food (as packed) carbohydrate and portion.

\begin{tabular}{|l|c|c|c|c|c|c|c|c|c|}
\hline & \multicolumn{3}{|c|}{$\begin{array}{c}\text { Greenhouse gas emissions, } \\
\text { kg CO} 2 \mathrm{e}\end{array}$} & \multicolumn{3}{c|}{$\begin{array}{c}\text { Blue water consumption, } \\
\text { I }\end{array}$} & \multicolumn{3}{c|}{$\begin{array}{c}\text { Blue water scarcity } \\
\text { footprint, I } \mathrm{H}_{2} \text { Oeq }\end{array}$} \\
\hline & Potato & Pasta & Rice & Potato & Pasta & Rice & Potato & Pasta & Rice \\
\hline Net weight (/kg) & 0.33 & 1.56 & 2.31 & 13 & 27 & 2407 & 3 & 24 & 2132 \\
\hline Carbohydrate (/g) & 1.80 & 1.97 & 2.97 & 76 & 34 & 3175 & 20 & 30 & 2813 \\
\hline Serving (/portion) & 0.05 & 0.12 & 0.17 & 2.3 & 2.1 & 181 & 0.6 & 1.8 & 160 \\
\hline
\end{tabular}

